\title{
Perception of nurses on the adhesion of partners of pregnant women with syphilis to the treatment
}

\author{
Percepção de enfermeiros sobre a adesão ao tratamento dos parceiros de gestantes com \\ sífilis
}

\author{
Percepción de enfermeros acerca de la adherencia al tratamiento de las parejas de \\ embarazadas con sífilis
}

Mayanne Santana Nóbrega de Figueiredo ${ }^{1}$, Edilma Gomes Rocha Cavalcante ${ }^{2}$, Célida Juliana de Oliveira ${ }^{2}$, Maria de Fátima Vasques Monteiro², Glauberto da Silva Quirino², Dayanne Rakelly de Oliveira²

Objective: to investigate the perception of nurses of the Family Health Strategy on the factors that influence adhesion to treatment of sexual partners of pregnant women with syphilis. Methods: it is a qualitative research, made with 10 nurses. To collect data, a semi-structured interview was used. The data were submitted to thematic analysis. Results: the following categories were identified: the approach of the nurses to partners of pregnant women with syphilis; barriers that influence on the adhesion to the treatment; strategies and actions of adhesion of the partners in the treatment; perception of the nurse concerning the responsibility of assistance and effectiveness of the treatment. Conclusion: it was identified that nurses have a wide perception of aspects relating to adhesion to the treatment, but need better scientific and practical basis to perform effectively activities on the management of sexual partners with syphilis.

Descriptors: Syphilis; Sexual Partners; Therapeutics; Nursing Care.

Objetivo: investigar a percepção dos enfermeiros da Estratégia Saúde da Família sobre os fatores que interferem na adesão ao tratamento de parceiros sexuais de gestantes com sífilis. Métodos: pesquisa qualitativa, desenvolvida com 10 enfermeiras. Para a coleta de dados, utilizou-se a entrevista semiestruturada. Dados submetidos à análise temática. Resultados: foram identificadas as categorias: abordagem das enfermeiras aos parceiros de gestantes com sífilis; barreiras que interferem na adesão ao tratamento; estratégias e ações de adesão dos parceiros no tratamento; percepção da enfermeira acerca da responsabilidade de seguimento e comprovação do tratamento. Conclusão: identificou-se que os enfermeiros possuem percepção ampla acerca dos aspectos relativos à adesão ao tratamento, mas necessitam de melhor embasamento científico e prático para realizar as atividades de maneira eficaz diante do manejo dos parceiros sexuais com sífilis.

Descritores: Sífilis; Parceiros Sexuais; Terapêutica; Cuidados de Enfermagem.

Objetivo: investigar la percepción de enfermeros de la Estrategia de Salud Familiar sobre los factores que influyen en la adherencia al tratamiento de parejas sexuales de embarazadas con sífilis. Métodos: investigación cualitativa, desarrollada con 10 enfermeros. Para recopilar los datos, se utilizó entrevista semiestructurada. Los datos fueron sometidos a análisis temático. Resultados: Se identificaron las siguientes categorías: enfermeras se acercan a parejas de las mujeres embarazadas con sífilis; barreras que interfieren con la adherencia al tratamiento; estrategias de adhesión y acciones de las parejas en el tratamiento; percepción de la enfermera sobre la responsabilidad del seguimiento y prueba del tratamiento. Conclusión: se identificó que los enfermeros tenían amplia percepción de los aspectos relacionados con la adherencia al tratamiento, pero necesitan mejor base científica y práctica para llevar a cabo eficazmente actividades sobre gestión de parejas sexuales con sífilis.

Descriptores: Sífilis; Parejas Sexuales; Terapéutica; Atención de Enfermería.

\footnotetext{
${ }^{1}$ Secretaria Municipal de Saúde. Mauriti, CE, Brazil.

${ }^{2}$ Universidade Regional do Cariri. Crato, CE, Brazil.

Corresponding author: Edilma Gomes Rocha Cavalcante

Rua Padre Redondo, 09, Vila Alta, CEP: 63.119-320, Crato, CE, Brazil. E-mail: edilma.rocha@yahoo.com.br
} 


\section{Introduction}

Syphilis is an infectious disease, which is a challenge for public health, especially when it affects women during pregnancy. In such cases, it has been identified that there is a proportional increase of congenital syphilis notifications that are related to sexual transmission, followed by vertical transmission during the pregnancy period ${ }^{(1)}$. Therefore, the notification of syphilis is an excellent indicator of prenatal care and quality puerperal both for maternal health as well neonatal ${ }^{(2)}$.

In this regard, the Health Department has launched programs and set up measures to reduce transmission of syphilis and its consequences, such as abortion and fetal malformation. Currently, these strategies have been intensified with the Stork Network, whose aim is to ensure care to women and children, the right to of a safe birth, healthy growth and development. For such, the access to syphilis and Human Immunodeficiency Virus (HIV) testing in primary health care has been widened ${ }^{(3)}$.

Concerning the recommendations for monitoring the diagnosis of syphilis in pregnant women, the exam of Venereal Disease Research Laboratory (VDRL) should be made in the first quarter of pregnancy, which needs to be remade in the third quarter and need to be repeated before birth at the time of admission to the ward. For pregnant women who did not have prenatal care, it is important to make the test before delivery ${ }^{(1)}$.

Concerning this screening and treatment, it was noticed, in 2011, that among women who had prenatal, $86.6 \%$ of pregnant women who were diagnosed with syphilis, only $11.5 \%$ had their partners treated ${ }^{(4)}$. Also, in a comparative study, cases of congenital syphilis occurred with 1,024 mothers between 2006 and 2011 in Campo Grande, MS, Brazil. In this study, the occurrence of other infectious diseases during prenatal care was observed, but there was no proper treatment of the couple in the case of syphilis and the screening of children was not carried out ${ }^{(5)}$. Thus, the lack of treatment of the partner is considered one of the challenges for the control of syphilis and the main cause of inadequate treatment, which can be identified in different regions of the country ${ }^{(6-7)}$.

This also shows that the number of appointments made by the pregnant woman during her prenatal assistance is not enough to ensure control of this infection, because besides the intention and the expansion to the access and minimum number of recommended appointments, it requires evaluation of the quality of their content ${ }^{(8)}$, particularly in primary health care where pregnant women and partners should be monitored and treated appropriately.

However, in another study, the difficulties of the Family Health Strategy team regarding leading the pregnant women and their partners to hospital and providing assistance were identified, although it was possible to carry out the search through the Community Health Agents, the health professionals presented lack of active posture for the partner to attend the service and showed lack of decision when taking the pregnant women to make the treatment at a specialized unit. Also they did not mention the compulsory notification of cases of syphilis in the pregnant women and congenital syphilis ${ }^{(9)}$.

As priority, the literature has pointed out the syphilis notification actions, active surveillance, adequate treatment of sexual partners and serological assistance that proves the cure of the disease, they represent activities to be performed in primary health care. Therefore, the importance of nurses in screening for syphilis during pre-natal care is outstanding in conducting health education activities and attraction of sexual partners for treatment ${ }^{(10)}$.

Such approaches are needed to modify the reality and contribute for the control of the incidence of syphilis. For this, there must be commitment of health professionals and managers in the pregnant woman's monitoring records and quality of prenatal care $^{(7)}$. Besides guaranteeing the opportune and adequate treatment of the partners, it is necessary to make use of strategies for the organization of the 
service and improvement of the quality and assistance of the cases $^{(6)}$.

Thus, the interest in the study was motivated by the desire to interpret and reflect on current elements of the disease and their consequences for the health of women and men in the activities to be performed in the routine activities of primary health care. This theme is important for the comprehension and transformation of the reality due to its scientific relevance facing the insufficient level of effective preventive and prophylactic measures against syphilis.

Considering the difficulty of the treatment of partners of pregnant women with syphilis, this study aimed at identifying the perception of nurses working in the Family Health Strategy, regarding the factors that influence on the adhesion to the treatment of their sexual partners.

\section{Method}

It is a qualitative research as it emerges facing the impossibility of investigating and understanding through statistics some phenomena focused on perception, intuition and subjectivity ${ }^{(11)}$.

The study was made in the county of Crato, located in the south of Ceará, at a distance of approximately $567 \mathrm{~km}$ from the capital, Fortaleza. It had a population of 122,717 inhabitants. It was made at the Family Health Units of the above mentioned county, which had 31 health teams with $87.15 \%$ coverage.

Study participants were nurses who met the following inclusion criteria: working in the Family Health Strategy in the city of Crato, CE, and having provided assistance and notification of syphilis cases during pregnancy from the 2005, the time when the disease was included in the list of compulsory notifications.

The survey was held in August and September 2010. For data collection, semi-structured interviews guide were used. The instrument was divided into two parts, in the first the information that characterizes the profile of participants was identified and the following data were included: gender, age, time since graduation, post-graduation and time of work. The second was composed of guiding questions of the study in order to know the approach of these professionals in carrying out active search for sexual partners of pregnant women with syphilis, as well as the aspects related to behavior cases record, guidance, treatment and difficulties that interfere on the adhesion to the treatment, using the following guiding question: Which perceptions and actions do the nurses use to limit the barriers of adhesion to the treatment of partners of pregnant women with syphilis in the Family Health Strategy?

The interviews were recorded after the consent of the participants, by signing the Informed Consent form and were later completely transcript. The analysis has respected the confidentiality of information provided, so the interviewees were identified by the initial N, referring to nurse, followed by an Arabic numeral according to the order of the interviews.

Data interpretation was done through thematic analysis ${ }^{(11)}$, which aimed at finding out the nuclei of the interviewees. For that, the researcher groups the data by topic and examines all cases in the study to make sure that all manifestations of each subject were included and compared in order to identify the existent relations ${ }^{(11-12)}$. Through empirical data four categories were elaborated: the approach of the nurses with the partners of pregnant women with syphilis; the identification of barriers that interfere on the adhesion to the treatment of syphilis; the primary actions taken for the adhesion of the partners in the treatment of syphilis; the perception of the nurse concerning the responsibility of monitoring and verifying the treatment of syphilis in pregnant women and sexual partners.

The survey complied with the requirements of Resolution 466/12 of the Health National Council, with approval of the project by the Committee of Ethics and Research of the Universidade Regional do Cariri, through the legal opinion number 07/2010. 


\section{Results}

\section{Characterization of participants}

The study included 10 of the 11 nurses who provided care to cases of pregnant women with syphilis in their health units. All study participants were female, aged between 25 and 37 years. Regarding the time since graduation, seven had more than five years of graduation, with only three nurses with less time. Eight of these nurses had specialization, mainly in Public Health and Family Health.

From the analysis of the interviews with the nurses, it was possible to establish the following categories: Approach of the nurses to partners of pregnant women with syphilis, Barriers that interfere on the adhesion to the treatment of syphilis,Strategies and actions of adhesion to the treatment of the partners in the treatment of syphilis and Perception of the nurse about the responsibility of monitoring and the response to the treatment.

\section{Category 1 - Approach of the nurses to partners of pregnant women with syphilis}

Concerning the approach they made with partners of pregnant women with syphilis, the nurses reported that for the active pursuit they chose, as first alternative, sending a statement through the wife requesting the presence of the partner at the service unit, but in case the partner did not attend, the Community Health Agents were asked to make the home visits to the couple and send the partner to the health unit. Still, it was reported that if the above mentioned alternatives were not successful, the nurse and the doctor visited their homes in the active pursuit of the partner. Initially I communicate the wife, since the access to her is easier once she is already there participating in the prenatal and the partner hardly ever follows her (N3). Once after all the information to the wife was provided, I communicate that it is necessary for the partner to come, and if the partner does not want to come, I call the health agent to provide active pursuit, and even then he does not go, the doctor and I make the home visits (N7).

From the statements, it is possible to verify that the nurses use various strategies to approach/invite the partner of the pregnant woman with syphilis to his treatment, and, primarily, this contact is encouraged to occur by initiative of the pregnant woman in the attempt to raise awareness in the partner in order to attend the health unit.

\section{Category 2 - Barriers that interfere on the adhesion to the treatment of syphilis}

In this category, the interviewees reported the barriers which limited the treatment. Aspects concerning the partner of pregnant women with syphilis were mentioned regarding to the level of schooling, the lack of knowledge about the disease and its consequences, which in turn can lead to conflict, when the male partners associate the occurrence to infidelity of the female partner. Health is linked to education, unfortunately the lack of knowledge of the patients is still a major obstacle. ...And the permanence of taboos and a certain machismo is unfortunate when it comes to sexually transmitted diseases (N1).

A fact pointed out in interviews that deserves attention when the nurse approaches the partners of pregnant women with syphilis, is represented by the type of relationship the couple maintains, as it is a stable union or not, leading to the conclusion that aspects which permeate fidelity should be treated with caution by professionals, which certainly supports the idea of a multifactorial treatment of these sexual partners. We must consider the stability and/or the type of relationship between the woman and her partner, that determines which conduct should be adopted (N10).

As to the administration of the drugs, the nurses reported the need to hear the complaints of the partners of pregnant women with syphilis in relation to pain, type of administration of the medicine and fear of side effects, besides taking the partners to the hospital which can delay assistance and the administration of the medicine. This condition was also pointed out by nurses as a possible break of the 
bond and the difficulty of confirming the treatment performed by the partner with syphilis. There are many complaints about the type of drug administration, fear of reactions, ... partners complain of pain, but also the long wait in hospital lines. And the fact that it is in the hospital, interferes in our monitoring, the link between us and the partners is often broken and this prevents us from being sure if the treatment has been properly made (N9).

It is then observed that the adhesion of the sexual partner to the treatment of syphilis permeates a multi-factorial setting, which involves from aspects related to his socio-economic, cultural and educational level to issues related to the treatment itself, such as medication and the health unit in which it is administered. Therefore, it is worth highlighting that the fact that the treatment is provided in a hospital is a factor of difficulty for the adhesion and supervision of treatment.

\section{Category 3 - Strategies and actions of adhesion to the treatment of the partners in the treatment of syphilis}

It is found that, in general, the interviewees consider the guidance on disease awareness about the effects on the fetus and health education as key actions for the adhesion of partners of pregnant women. They also attributed importance to their participation in prenatal care, to the guarantee of access to health services, especially regarding the treatment. I see the orientation and the quality of information as fundamental. health education is needed, I insist on this issue (N5). It is necessary that the information is clear and clarify the main doubts (N3). The professional must establish a relation of trust (N7). The participation of the partner in prenatal care is very important. His participation at least in the first appointment should be required (N4). In addition to the awareness of the disease it is necessary to ensure free access to the unit and especially to the treatment (N9).

The statements allow us to say that for nurses the qualification of pre-natal care with the participation of the partner of the pregnant woman in the appointments, associated to a clarifying approach which establishes trust, is essential to the treatment. It is worth observing that in their opinion, the health service must guarantee access and timely treatment, leading us to suggest that they should be provided at the very basic health unit.

\section{Category 4 - Perception of the nurse about the responsibility of monitoring and the response to the treatment}

Concerning the investigation to prove that the treatment of pregnant women with syphilis and their sexual partners is successful, the nurses showed their influence in the practice that covers important axes at the reception and monitoring of partners when they include guiding, reception and monitoring, besides an ethic posture free of judgment of value. It is needed to guide and welcome not only the woman but also the partner without judging him as guilty, intervening ethically, without going into the intimate life of the couple (N1).

Regarding the treatment, the value attributed to the monitoring and to the guarantee of the administration of medicine, even if it was provided in other health unit, was observed. As well as ensuring the efficacy of treatment which should be verified from the register of the treatment in the pregnant woman's card, once it would be an important indicator of the treatment. This condition was reported by a nurse, once the other ones had the verbal confirmation of the treatment by pregnant women and their partners. Because the medication is not provided at the unit, it is crucial to guarantee it and monitor its administration. Its register must be made in the card of pregnant woman after the administration to be certain that it was provided (N8).

The participants also emphasize, in their actions, the importance to the effectiveness of assistance, assuming that they attribute fair importance to the assistance, considering it the ideal time to assess implemented conduct and effectiveness 
of the treatment as well the adhesion of the couple to the guidance. When there is no return of the patient, I see that it is necessary to call the health agent to make sure that the medication was provided (N10).

In general, the statements lead to the reflection on the approach of the professional nurse in warm respectful manner, free of judgments which can keep the users of the health unit away, with the objective to favor their adhesion to the established conduct. Once again, the fact that the medication is not administered at the family health unit appears as a complicating factor in this particular case observed in the statement above for the assistance of the treatment.

\section{Discussion}

In the practice of taking care of the partners of pregnant women with syphilis, nurses reveal important opportunities and barriers to have their adhesion to the treatment, responsibility in the assistance and in the effectiveness of the treatment.

Regarding their approach to the partners of pregnant women with syphilis in this study, two alternatives of search used by nurses were mentioned, such as requesting the presence of the partners at the basic health unit after the communication of the wife concerning the diagnosis of syphilis, and in cases of resistance, they called other members of the health team (community health agents, nurses or doctors) to visit their home.

Considering the complexity of the approach of the partners of pregnant women with syphilis, studies consider inappropriate that the health professionals transfer to the wives the responsibility to take the requests of the exams or treatment to their partners without their presence at the health units ${ }^{(12-13)}$, once providing information or hiding the diagnosis from the partners can jeopardize the break of the transmission of the disease $\mathrm{e}^{(14-15)}$.

Thus, the appropriate course of action to be carried out by health professionals is the direct approach, provided that they are trained and experienced, for showing more competence and less difficulty to approach men with syphilis ${ }^{(13)}$. Other commitments that have also been required to health units run by the Stork Network, are the new proposals for diagnosis of syphilis though rapid tests at health units as well as the need to modify the failed strategies of the past decades ${ }^{(3)}$.

These proposals aim at providing more solution and quality to the health professionals with the pregnant women and their partners in the control of syphilis and sexually transmitted diseases in general, using simple prevention measures and more accessible technological devices. Otherwise it will show the negligence of health units, which is reflected in high rates of untreated pregnant women and their partners ${ }^{(6,7)}$, which is also a reality in the Unified Health System of the state of Ceará and consequently enhancing the incidence of vertical transmission ${ }^{(16)}$.

So, the weaknesses of the actions used by nurses of the Family Health Strategy to welcome, advise, treat and support the marital relationship of the partners facing the experience with syphilis requires making activities, even if they do not have as focus only prescriptive actions.

In this study, the nurses highlighted some weaknesses as non-adhesion to the treatment, which were related to the partners of pregnant women, such as level of education, lack of knowledge of the disease, work activities, level of relationship with the mother and absence at the prenatal. Some of these aspects related to the partners or the practice of health professionals can influence adhesion or non-adhesion to treatment of syphilis, according to studies ${ }^{(13-14)}$.

Regarding the marital relationship and the absence of the partner at the prenatal, this distance between health professionals and men interferes in the recognition of needs of the family and in the proper assistance, once the partner is unaware of the disease 
itself and for not participating in the appointments with the pregnant woman, does not receive valuable information which can justify the need of control of the syphilis.

Other barriers to the adhesion to the treatment pointed out by nurses of the Family Health Strategy were related to the administration of medication for syphilis, in which they reported the need to hear the complaints of the partners of pregnant women, as they presented reactions of fear and pain when receiving intramuscular medicine. These reactions were also identified in a study with partners of pregnant women, which resulted in refusal of treatment for not believing being sick or by fear of injection ${ }^{(14)}$.

Thus, the difficulty of the partners to complete the treatment should be a cause for investigation, both to establish his profile as well as to identify their vulnerabilities and individual needs, which can direct the nurse or the health team to ensure a complete care and to adopt more effective strategies of interventions.

In the same study, the barriers which include the organization of health units were identified such as leading the partners with syphilis to the hospital, which culminated in more time for care and administration of medication, and the loss of bond and difficulty to achieve effectiveness of the treatment made by the partner with syphilis. Considering those limitations, the dynamics of a health unit must guarantee access to services, provide welcoming and counseling, educational assistance, calling, treatment of partners and effective assistance of the cases, once many of them did not receive treatment or had inadequate treatment ${ }^{(6)}$.

However, considering the practice of primary health care, the difficulty of adhesion or the absence of the partners of pregnant women, this is a historically elaborated process and reproduced by programs and care networks with an almost exclusive focus on the maternal and child care ${ }^{(16)}$. Confirming the result of such exclusion, a study on the incidence and control of congenital syphilis in Ceará, Brazil, showed that despite noticing the high number of pregnant women in prenatal care, their partners were not treated, reinforcing the underreporting in the notification/ investigation and, mainly the ineffectiveness in the control of syphilis ${ }^{(17)}$.

Thus, to modify access to this demand it is for the health professionals to cover all the possibilities, which requires continuous efforts, effective measures, especially of nurses in actions of prevention and control of syphilis, once implemented from a ethical and shared relation, sustained in the commitment to provide security to the patients with the solution of his problems, once the treatment of the partner is determinant in order to have effective cure of the disease which affects the family ${ }^{(10)}$.

In this study, the nurses mentioned the importance of priority actions to help the adhesion to the treatment from the health education focused on guidance on the disease, awareness of the effects on the fetus, as well as participation of the partner at the prenatal, the access to the services and to the treatment.

Although this study did not find reports of group activities and health education related to syphilis and/or sexually transmissible infections, it is assumed that health education should be provided according to the importance attributed in the statements. It is considered that this process of work should add actions in which pregnant women and partners receive advice and explanations about the disease, following the recommendations of the Health Department ${ }^{(18)}$. In this context, health education is an emancipating process of thinking and doing for the emancipation of the person and the population ${ }^{(19)}$. Therefore, it is an essential tool of work of nursing care, which must involve health professionals committed in ensuring educational practice in health involving the family and the community.

In general, the greatest challenge for the health 
units is the implement of proactive actions of health care professionals facing their social and health responsibility of cases of syphilis in pregnant women and partners, which reinforces the need for changes in practice, so that the prevention of diseases and promotion of health in the control of the disease can prevail.

Still, in this study, the perception of the nurses as to the responsibility and importance for the monitoring and the cure of the syphilis include competent professionals and assertiveness of communication between the health professional and the patient, provided that it is present in the process of care, in the assistance, the welcoming, the monitoring and ethical care to ensure access to the service and the registration identification confirming the treatment of pregnant women and partners, that directly interfere in the efficiency, quality and cost of care.

Facing those considerations, the health professionals should proceed in the work of permanent transformation for the quality rendered at the prenatal and delivery coping with the limits and potentialities present in the reality. Monitoring and investigation of the cases of syphilis in pregnant women and their partners are essential, they include information, education, communication from a dynamic and participating process for the comprehension of the epidemiological situation and clarifies, in a more personalized way, the doubts and fears of the users ${ }^{(18)}$.

Consequently, the access to the treatment and other care to be developed by the health professionals at an earlier stage, has pointed to the need to use a ratio of the observed cases on the estimated cases of syphilis during pregnancy close to 1.0, provided that the number of pregnant women who perform prenatal in primary care is considered as a possibility of interaction of monitoring in health and assistance ${ }^{(20)}$, the cases should be closed, especially with the register of the treatment and control of the cure which are decisive to prevent vertical transmission ${ }^{(18)}$.
As for the ethical care, appropriate to the disease experienced by the couple, they should receive support, however, without suffering responsibility or blame by the health professionals. Considering these last responses prejudice, when the health professionals are still in the process of training, once they provoke fear and discrimination ${ }^{(21)}$.

Blaming the behavior of the patient can be expressed by health professionals who need to know other issues involving social determinants of health, especially assertive communication ${ }^{(22)}$ which can make the adhesion to the treatment easier, decrease anxiety and be in instrument in the management of the stress of the health professionals.

So, the communication showed by the nurses, in the present study, has the objective to avoid failures and to value the meeting with the partners of pregnant women with syphilis, besides pursuing initiatives that favor the bond, so that the agreements and responsibilities can be established aiming at the success in health care.

\section{Final Considerations}

The study showed the perceptions and actions of the nurses of the Family Health Strategy as to the factors that influence on the adhesion to the treatment of partners of pregnant women with syphilis. It was found that for nurses, the qualification of prenatal care is an essential factor to assure proper treatment of partners of pregnant women with syphilis, emphasizing the participation of the partners at the prenatal appointments. It is worth highlighting that a relation of trust, focused on a clarifying approach on the disease and the treatment was also considered crucial for the adhesion of the partners to the treatments.

The study highlighted the reflection on the issue of the treatment not being made at a basic health unit, considered as an aspect which makes access, implementation and supervision of treatment 
difficult. From these considerations, it is expected that this study can contribute to a differentiated action of the nurse facing syphilis and rethink the effective practice to overcome this problem of public health.

\section{Collaborations}

Figueiredo MSN and Oliveira DR contributed in the conception, analysis and interpretation of data. Cavalcante EGR, Oliveira CJ, Monteiro MFV and Quirino GS collaborated in the writing of the article, including their critical revision of the intellectual content and final approval of the version to be published.

\section{References}

1. Lenz MLM, Flores $R$, organizadores. Atenção à saúde da gestante em Atenção Primária à Saúde. Porto Alegre: Hospital Nossa Senhora da Conceição; 2011.

2. Leitão EJL, Canedo MCM, Furiatti MF, Oliveira LRS, Diener LS, Lobo MP, et al. Sífilis gestacional como indicador da qualidade do pré-natal no Centro de Saúde número 2 Samambaia-DF. Comun Ciênc Saúde. 2009; 4(20):306-14.

3. Ministério da Saúde (BR). Secretaria de Vigilância em Saúde. Departamento de DST/Aids e Hepatites Virais. Realização do teste rápido para HIV e sífilis na atenção básica e aconselhamento em DST/ Aids. Brasília: Ministério da Saúde; 2012.

4. Ministério da Saúde (BR). Secretaria de Vigilância em Saúde. Departamento de DST/Aids e Hepatites Virais. Boletim epidemiológico. Sífilis. Brasília: Ministério da Saúde; 2012.

5. Figueiró-Filho EA, Freire SS, Souza BA, Aguena GS, Maedo CM. Sífilis e Gestação: Estudo comparativo de dois períodos (2006 e 2011) em população de puérperas. J Bra Doenças Sex Transm. 2012; 24(1):32-7.

6. Magalhães DMS, Kawaguchi IAL, Dias A, Calderon IMP. Sífilis materna e congênita: ainda um desafio. Cad Saúde Pública. 2013; 29(6):1109-20.
7. Campos ALA, Araujo MAL, Melo SP, Gonçalves MLC. Epidemiologia da sífilis gestacional em Fortaleza, Ceará, Brasil: uma agravo sem controle. Cad Saúde Pública. 2010; 26(9):1747-55.

8. Magalhães DMS, Kawaguchi IAL, Dias A, Calderon IMP. A sífilis na gestação e sua influência na morbimortalidade materno-infantil. Comun Ciênc Saúde. 2011; 22(Supl 1):43-54.

9. Bittencourt RR, Pedron CD. Sífilis: abordagem dos profissionais de saúde da família durante o prénatal. J Nurs Health. 2012; 2(1):9-17.

10. Oliveira DR, Figueiredo MSN. Abordagem conceitual sobre a sífilis na gestação e o tratamento de parceiros sexuais. Enferm Foco. 2011; 2(2):108-11.

11. Minayo MCS. O desafio do conhecimento: pesquisa qualitativa em saúde. 12a ed. São Paulo: Hucitec; 2010.

12. Domingues RMSM, Hartz ZMA, Leal MC. Avaliação das ações de controle da sífilis e do HIV na assistência pré-natal da rede pública do município do Rio de Janeiro, Brasil. Rev Bras Saúde Matern Infant. 2012; 12(3):269-80.

13. Domingues RMSM, Lauria LM, Saraceni V, Leal MC. Manejo da sífilis na gestação: conhecimentos, práticas e atitudes dos profissionais pré-natalistas da rede SUS do município do Rio de Janeiro. Ciênc Saúde Coletiva. 2013; 18(5):1341-51.

14. Campos ALA, Araújo MAL, Melo AP, Andrade RFV, Gonçalves MLC. Sífilis em parturientes: aspectos relacionados ao parceiro sexual. Rev Bras Ginecol Obstet. 2012; 34(9):397-402.

15. Cavalcante AES, Silva MAM, Rodrigues ARM, Mourão Netto JJ, Moreira ACA, Goyanna NF. Diagnóstico e tratamento da sífilis: uma investigação com mulheres assistidas na atenção básica em Sobral, Ceará. J Bras Doenças Sex Transm. 2012; 24(4):239-45.

16. Costa CC, Freitas LV, Sousa DMN, Oliveira LL, Chagas ACMA, Lopes MVO, et al. Congenital syphilis in Ceará: epidemiological analysis of one decade. Rev Esc Enferm USP. 2013; 47(1):149-56.

17. Ximenes IPE, Moura ERF, Freitas GL, Oliveira NC. Incidência e controle da sífilis congênita no Ceará. Rev. Rene. 2008; 9 (3):74-80. 
18. Ministério da Saúde (BR). Secretaria de Vigilância à Saúde. Departamento de DST/Aids e Hepatites Virais. Manual de teste rápido para sífilis. Brasília: Ministério da Saúde; 2012.

19. Leite CT, Vieira RP, Machado CA, Quirino GS, Machado MFAS. Prática de educação em saúde percebida por escolares. Cogitare Enferm. 2014; 19(1):13-26.

20. Saraceni V, Miranda AE. Relação entre a cobertura da Estratégia Saúde da Família e o diagnóstico de sífilis na gestação e sífilis congênita. Cad Saúde Pública. 2012; 28(3):490-6.
21. Seidl EMF, Ribeiro TRA, Galinkin AL. Opiniões de jovens universitários sobre pessoas com HIV/ AIDS: um estudo exploratório sobre preconceito. Psico-USF. 2010; 15(1):103-12.

22. Grilo AM. Relevância da assertividade na comunicação profissional de saúde-paciente. Psic Saúde Doenças. 2012; 13(2):283-97. 